\title{
Editorial $^{*}$
}

\section{GERRIE F. SNYMAN (UNISA)}

It is again a privilege to present an issue of Old Testament Essays with a variety of topics yet in some way related to each other. There are articles on the prophets, the psalms, wisdom literature, Hebrew narratives and a deuterocanonical book. Some articles deal with problematic aspects of biblical literature, other articles relate the text to a particular community of readers' context.

There are two articles and a brief note dealing with the book of Psalms. Pierre Auffret offers us a brief explanation on an aspect of the structure of Ps. 26. Aron Pinker looks at Ps 90:10, claiming that the last colon of MT is a minor

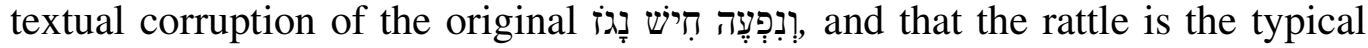
death groan. Phil Botha argues that the expression "tracks of righteousness" found in Psalm 23 possibly displays a direct link to Prov 2:9 and 4:11. He implies that the author of Ps 23 fused the metaphor of Yahweh as a shepherd (and as a host) with that of Yahweh as a guide on the road of life so that the suppliant is portrayed as a righteous person.

Picking up on Proverbs, Madipoane Masenya provides what she calls a holistic African-South African reading of Proverbs 6:6-11. She explores here the inter-connectedness between human beings and nature. This inter-connectedness serves as the basis to postulate a holistic approach which she then ties to Yehud as well as to some proverbs in African societies.

Quite a few articles on aspects of the prophetic books focus on African contexts. Takuze Chitsulo explores the role of the wicked in Habakuk within the context of the sociopolitical and political environment in Malawi. Matthew Michael uses his Nigerian context to inquire into the topic of anger. He looks at the consistent literary patterns in the representation of angry scenes in Hebrew narratives, identifying the different stages in biblical angry exchange scenes. Samson Olanisebe also looks at the issue of anger. He reads Isa 5:1-7 and asks questions about the justice of God in his anger and the implications for socioeconomic and security challenges in Nigeria. Georg Fischer, residing in Austria, asks questions about the relevance of Jeremiah for South Africa. He argues that suffering, problems, injustice can all be resolved, if they are addressed in a manner similar to the way in which Jeremiah dared to speak out and to advocate God's view in his own times.

Two more articles deal with prophetic books. Blessing Boloje and Alphonso Groenewald demonstrates the significance of covenant as the central

\footnotetext{
To cite: Gerrie F. Snyman, "Editorial: Epistemic Vulnerability,” OTE 28/2 (2015): 241-42, DOI: http://dx.doi.org/10.17159/2312-3621/2015/v28n2a2
} 
and cohesive theological motif connecting and coordinating several themes present in the book of Malachi. Pieter de Vries looks at the relation between the concept of the glory of YHWH and the Spirit of YHWH. He argues that the latter is the prerequisite for the return of the glory of YHWH.

Related to the spirit of YHWH is Shaul Bar's article on incubation dreams in the Hebrew Bible. Such dreams tell the story of people who would go to sacred places, offer sacrifices to God, and fall asleep hoping that God will visit them in a dream. Evidence for such dreams are Solomon's dream at Gibeon (1 Kgs 3:4-15), Jacob's vision at Beer Sheba (Gen 46:1-7), Balaam's vision (Num 22-24) and Isaiah's dream (Isa 65:4). However, Bar is more skeptical of Abraham's dream (Gen 15) and Samuel's dream (1 Sam 3) as incubation dreams.

Paul Kruger taps into the research of emotions in the Hebrew Bible. Given the figurative language into which emotions are casted in the Hebrew Bible, it is quite difficult to name the particular emotion in the text. He discusses what emotion entails in the Hebrew text, the limitations of the original psychophysical approach and the cognitive approach, the question of a dominant conceptual metaphor; as well as the social-constructionist view of emotions

Risimati Hobyane looks at the message of the book of Judith with the help of the actantial model of Greimas. He concludes that the Judith narrative was aimed at revitalising Jewish religious patriotism during the difficult times of the Second Temple period.

Two articles relate to ecological aspects in the reading of the biblical text. Esias Meyer is interested in how land (אֶרץ) is personified in the Holiness Code. He argues that the ancient authors of the Holiness Code knew about the intrinsic worth of אריץ ארץ and that without itself was not possible. He problematizes Norman Habel's Earth Bible project in suggesting that the Hoiliness Code refers to Canaan and not what one would call earth or Earth. He says that the ancient authors could not think of their relationship with YHWH without at the same time thinking of אֶ:

Peet van Dyk, in turn, questions the term "responsible stewardship." $\mathrm{He}$ argues that the latter may constitute a hidden new way to affirm human dominion, human arrogance and anthropocentrism. He suggests that that the terms "reluctant interference" or "careful interference" should rather be used than the concept of "responsible stewardship."

Gerrie Snyman, Editor, Old Testament Essays. Department of Biblical and Ancient Studies, Unisa. Email: snymagf@unisa.ac.za or ote-editor@otwsaotssa.org.za. 